\title{
Neighbourhood Patterns in Istanbul: From Historical Form to Manhattanization
}

Gülden Demet Oruç ${ }^{*}$ Özhan Ertekin ${ }^{\star *}$ Vedia Dökmeci ${ }^{\star \star \star}$

\begin{abstract}
During the last century, the transformation of Istanbul's urban structure from monocentric to multi-centric and its rapid population growth resulted in neighbourhood patterns which are spread across a large spectrum according to their location and their cultural, socio-economic and historical backgrounds. In urban settings, the potential environment is reinterpreted by its users, and is realized through the application of the space and time-specific societal norms within the context of technological advances. The present study investigates the selected neighbourhood patterns from historical to westernized, modern, postmodern (gated) and Manhattanized forms.
\end{abstract}

According to the results of the study, although some of the historical, westernized and modern neighbourhoods have been preserved to a large extent, the haphazard development of high-rise residential buildings has caused traffic congestion, pollution, an increased income gap and changes in land values, and has thus produced functional transformations in their immediate surroundings. In addition, this unnecessary increase in housing density is not only harmful for the city's famous silhouette but also for its traditional neighbourhood relationships. In order to allow a physically, economically and socially more balanced development of the city, it is necessary to control its
Keywords: Istanbul, historical, modern, neighbourhood pattern, post-modern, westernized

* Assist.Prof.Dr. Urban and Regional Planning Department, Istanbul Technical University, İstanbul, Turkey

E-mail: guldenoruc.itu@gmail.com

Orcid ID: http://orcid.org/0000-0003-4303975X

** Assoc.Prof.Dr. Urban and Regional Planning Department, Istanbul Technical University, İstanbul, Turkey, (Corresponding author) E-mail: ertekinozhan@gmail.com Orcid ID: http://orcid.org/0000-0003-09932878

*** Prof.Dr. Emeritus, Urban and Regianal Planning Department, Istanbul Technical University, İstanbul, Turkey E-mail: dokmeciv@itu.edu.tr Orcid ID: http://orcid.org/0000-0002-29459910 
growth and follow a system of planned development which is not solely for the benefit of real estate investors. It is hoped that the results of the study will be useful for the urban and regional planners, policy makers and investors.

\section{INTRODUCTION}

Istanbul has a large spectrum of neighbourhood patterns that date from the Byzantine era to modern times. The physical environment of the city has always been an arena for potential actions and interpretations on the part of its users within the context of cultural, socio-economic and technological conditions (Yazgi and Dokmeci, 2006). Hunter (1979) analysed neighbourhoods by typologies and their stages of change and functions with respect to economic, political and social characteristics. The results of that study revealed that the urban neighbourhood is a unique locus of the convergence of these elements. Accordingly, the urban form is basically an expression of the values of its users, as shaped by the forces of tradition, by communal reaction and by physical constraints (zoning, planning, etc) (Jo, 1998; Whitehand, 1981). In a later period, the conspicuous consumption of post-modern urbanism is reflected in numerous ways by the economic and cultural shifts in the society and, in turn, helps render them visible (Mitchell, 2000), thereby causing the transformation of neighbourhoods. In sum, the physical, social, cultural, economic, and political components and their different combinations come together and cause changes in the urban fabric (Asami et al., 2000; Whitehand, 2001; Yazgi and Dokmeci, 2009). The present paper investigates neighbourhood development in Istanbul from the historical to the westernized, modern, post-modern, gated neighbourhood and Manhattan-type forms by taking into consideration their different characteristics.

There are several studies which investigate the evolution of neighbourhood patterns in developed countries at different time periods and from different perspectives. Southworth and Owens (1993) examined neighbourhood patterns with respect to street and house lot in the San Francisco bay area. The study identified the underlying organizing principles and spatial typologies and analysed patterns of growth, land use, and street layouts for several periods of suburban development, from the early twentieth century to the 1990s. According to their results, it is possible to state that as the scale of development grows, there is an erosion of the public street framework, and this has serious implications for the character, convenience and adaptability of new urban environments. In another study, Brower (1992) investigated five different urban forms that focused on different 
cultures and periods. The common factor of these five research studies was that they all focused on the effects on urban forms.

McCann (1995) analysed neo-traditional developments which are built at a small scale and which incorporate many features of certain old-city neighbourhoods, such as narrow streets and small set-backs. These neighbourhoods have been designed by architects and built by small developers on suburban greenfield sites since the early 1980s. Mesev, et al., (1995) attempted to define the urban form according to two different variables: land use and density. In another study, Audirac (2002) attempted to explain the relationship between information technology and the urban form. Moreover, Song and Knaap (2004) examined the spatial analysis of the urban form in different neighbourhood units. The main variables of their study were the circulation system, density, land use, accessibility and pedestrian accessibility. These variables were compared for two different neighbourhood units. In his work, Conzen (2004) explored various ways of identifying and understanding the character of historic townscapes from a systematic and comparative perspective. He outlined both general and genetic approaches to the study of urban form which were grounded in the traditions of geographical analysis.

Jabareen (2006) identified sustainable urban forms and their design concepts. This study listed four types of sustainable urban forms: the neo-traditional development, the urban containment, the compact city, and the eco-city.

The review of previous studies illustrates that there are different approaches that may be used to explain the development of neighbourhood forms in different countries. The present paper analyses different neighbourhood forms in Istanbul, as an example from a developing country that has a long history. The organization of the present paper is as follows. General information is given about the development of Istanbul socioeconomic conditions and structure of Istanbul through time in the second section. In the third section, examples of historical, westernized, modern, post-modern (gated) and Manhattan-type neighbourhood patterns are illustrated. The final section is devoted to conclusions and suggestions for further research.

\section{BACKGROUND INFORMATION ABOUT ISTANBUL}

During the last half-century, Istanbul was transformed from a mono-centric to a polycentric city (Dokmeci and Berkoz, 1994), its population increased from one million to approximately 15 million, and the number of neighbourhoods rose from 581 in 1985 
to 989 in 2016. The provision of housing, services, public facilities and infrastructure has not kept pace with the rapid population increase and subsequent urban sprawl. This rapid expansion has affected the quality of life in various sections of the city; while some modern districts have become comparatively more attractive, the historic districts have lost population due to the deterioration of their neighbourhoods. Thus, much of Istanbul is undergoing rapid and continuous social, economic and structural change. This creates locational advantages and disadvantages which are reflected in the urban land markets and which have resulted in intra-urban migration from the decaying historical districts to the modern districts at the periphery (Dokmeci, et al., 1996).

In the 1960s, the majority of employment opportunities in Istanbul were concentrated in the core of the city. (Dokmeci and Berkoz, 1994). Over time, this has changed, and currently, the periphery has higher employment ratio than both the core and the intermediate zone. This shift has altered employment patterns, resulting in continuous urban development, as well as income growth and changes in social values, and has caused a higher rate of residential mobility. At the same time, a large amount of public housing construction in some of the peripheral districts has stimulated the growth of these districts but has also created a trend toward living in modern housing establishments surrounded by green areas and internally-supplied with all the necessary facilities (Dokmeci, et al., 1996). Following the expansion of the city in the 1970s, which was due to population increase, mostly as a result of rural migration (Yazgi et al., 2014), and the construction of the bridges over the Bosphorus and their associated peripheral highways, a new spatial structure has emerged, resulting in decentralized employment and related services. Increased highway development and airline connections have contributed to the development of a CBD which is more toward the north, rather than its historical location near the port. As a result, the area of the old CBD started to decline. In addition, during this period, the increased use of private automobiles was clearly incompatible with the economic, cultural and physical fabric of the city-centre of Istanbul, which was more oriented towards pedestrians and public transport. Consequently, the narrow streets became clogged with motor vehicles, and noise and pollution reached intolerable levels, endangering the general character of the old city centre. The decline of the CBD and the limitation of its growth due to its historical characteristics may be considered sufficient condition for the multi-centre development of the city. Increases in population, services, housing and land prices created a heavy demand for floor space in the sub-centre, 
thereby pushing vertical development in these areas (Senturk and Dokmeci, 2010).

Thus, due to the structural, social and economic changes in the city, the old districts are losing population and employment opportunities due to their deteriorating urban structure; as a result, housing demand and potential rates of return are low. In contrast, areas at the periphery that are near sub-centres with modern office buildings and modern residential settlements, both demand and potential rates of return are high (Dokmeci and Berkoz, 2000). There are several urban studies, which have attempted to explain the shifts within urban hierarchies and intracity spatial changes through the global restructuring of the capitalist society (Sassen, 1994; Castells, 1994). According to previous research by Dokmeci et al. (1996), which was based on a survey conducted at the city level, $70.8 \%$ of the respondents expressed a desire to relocate due to the restructuring of the urban space. This high percentage can be explained by the continuous expansion of the city, the increasing number of migrants, and the transformation of the urban structure and the associated social and economic values. Usually, migrants are more mobile than the rest of the city's population as they have already made the decision to move, a point which was also illustrated by Ahmad (1992). Of those who wanted to relocate, $67.8 \%$ wanted to live in an apartment, $8.9 \%$ preferred to live in a private house and 23.3\% preferred a "squatter" (illegally-built, usually on public land) house. These results corresponded to the income distribution of Istanbul.

The population size between neighbourhoods varies greatly in Istanbul. In general, historical neighbourhoods have small population sizes of between 5,000-6,000, whereas new neighbourhoods at the periphery often have very large neighbourhoods with populations between 40,000 and 50,000 (Figure-1). The results for the distribution of income per capita also show high levels of spatial disparity among the neighbourhoods. Usually, income per capita increases for neighbourhoods located on the seashore and decreases as the distance increases from the seashore, except for gated neighbourhoods. According to the previous studies, there is a relationship between the size and heterogeneity of neighbourhood s and their neighbourhood identity (Bardo, 1984). Usually, neighbourhood identity is stronger for historical neighbourhoods than the newly developed neighbourhoods at the periphery, especially those with high population densities. 
Figure 1. Spatial Distribution of Different Size Neighbourhoods

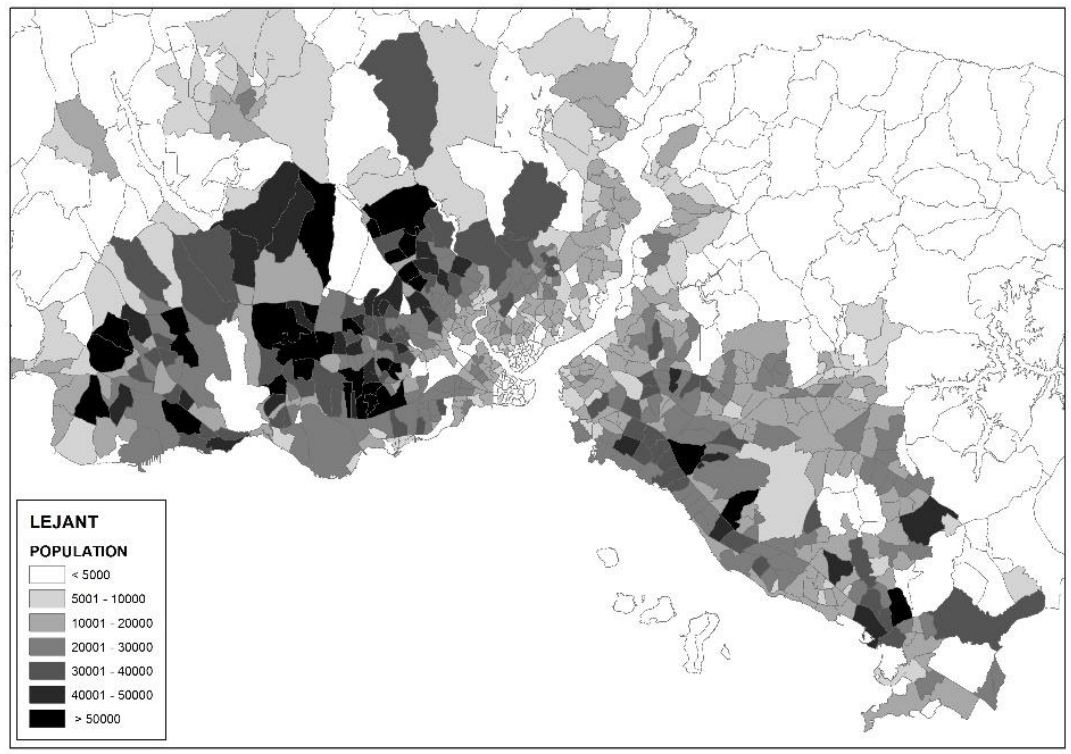

\section{CURRENT NEIGGHBOURHOOD PATTERNS IN ISTANBUL}

In this section, five types of neighbourhood pattern are taken into consideration, as historical, westernized, modern, post-modern (gated) and Manhattan-types.

\section{Historical Neighbourhoods}

For this study, two neighbourhoods which have structural traces and monuments from the Roman, Byzantine and Ottoman periods were selected from the Historical Peninsula. Each period had both a cultural and a social impact on the urban structure of the city. After the Ottoman conquest, new urban policies, a new type of urban administration, new institutions and new building types were established. A very segmented and labyrinthine urban fabric characterizes the Ottoman period. This is especially apparent from the formation of large and irregular urban blocks penetrated by numerous culs-de-sac which maximize interpersonal communications as claimed by Lynch and Rodwin (1958). The neighbourhood takes its form from the spanning narrow, curved streets that spread out from a core which consists of a small mosque (mescit) and a school (Aksoy, 1968). During the 19th century, a grid system was implemented in the neighbourhoods as in the case of Samatya which were destroyed by fire in order to better provide sewage and water systems (Figure-2).

Two historical neighbourhoods, which have preserved their residential characteristics, namely Balat (Jewish origin) and Samatya (Armenian origin) and these were restored by UNESCO in cooperation with the Municipal government (Gur, 2015) (Figure-3). Although most of the natives from these neighbourhoods do not live there anymore, as is the case in several other historical cities (Laskin, 2016), centuries of history 
cannot but make their marks on the soul of a place, thereby rendering it more attractive for new generations.

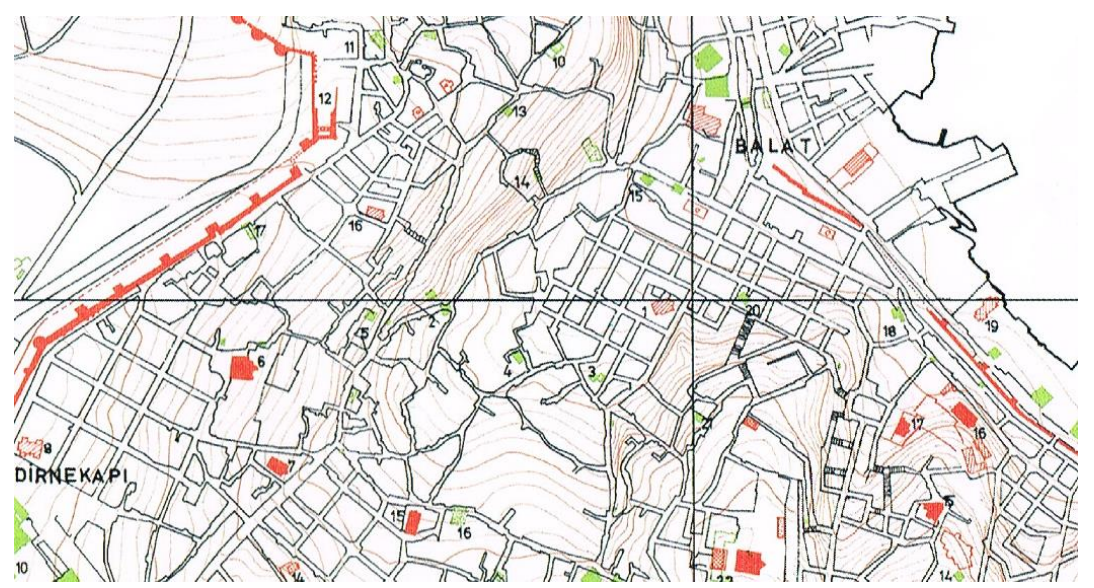

Some of the historical neighbourhoods are characterized by land and structure usage rapidly changing from residential to commercial (Kolcu, 2013). If the historical neighbourhoods are near an important historical monument or near the old CBD, the houses have been transformed into boutiques, hotels, commercial ventures and restaurants. This has occurred in the Cankurtaran area of Istanbul, largely due to pressure from tourism, and reflects what has occurred in other developing countries (Dix, 1990; Rahman, 1993). Additionally, it is possible to state that a small amount of transformation from residential to other functions has taken place. The transformation of historical neighbourhoods from residential to other functions in the historical peninsula of Istanbul was comprehensively explained by Ergun and Dundar (2004). Some of the lots have lost the original aspects of their design characteristics, but those which can be characterized as having stable land uses and structures, remain almost the same as their initial design; the older order still prevails. However, some of the neighbourhoods constitute a composite structure of new and old buildings existing side by side (Gur, 2015). There are also neighbourhoods which have the character of a reconstructed society (the commercial zone) and of a statement of historical continuity (the residential zone). This dual character has value spatially as well as historically. Knowledge of those physical forms, including their historical-geographical patterns of change, is likely to become even more important in the new century than it has been so far (Whitehand et al.,1999).

Usually, the existing settlement structure resists the introduction of new transport technologies. Therefore, those technologies which can adapt to the existing system allowed for developments which are crucial for solving traffic congestion in these neighbourhoods.
Figure 2. Ottoman and Westernized Neighbourhoods in the Historical Peninsula (Müller-Wiener, 1977) 
Finally, spatial differentiation, change and transformation are merely the means to resolve the balance. Unfortunately, the haphazard development in Istanbul does not often allow the urban structure to achieve a peaceful balance.

\section{BALAT}
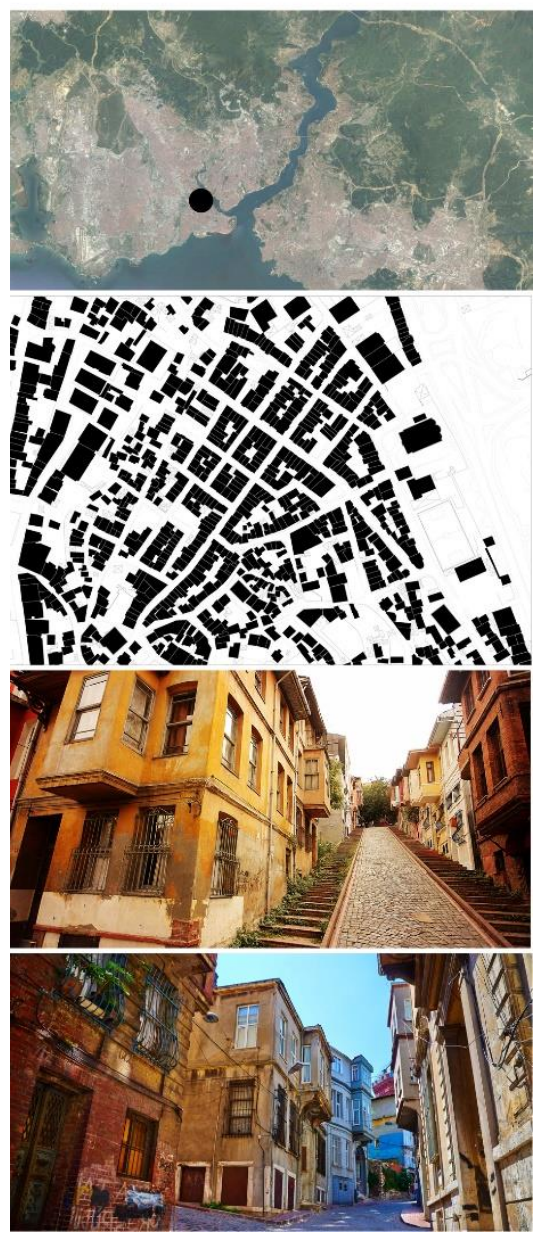

\section{SAMATYA}
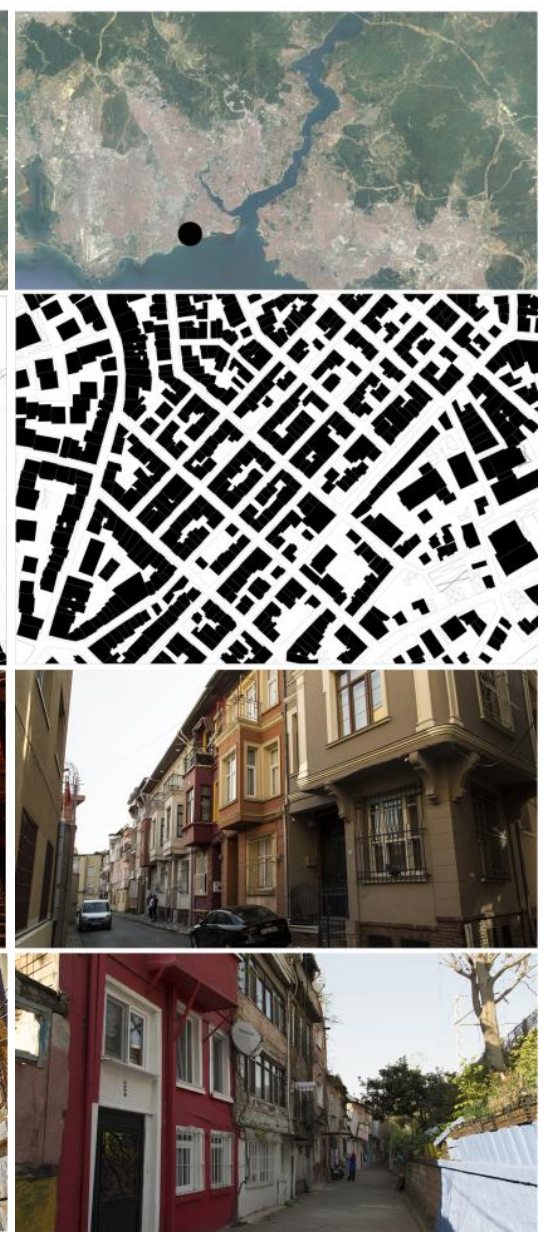

Figure 3. Balat and Samatya Neighbourhoods

\section{Westernized Neighbourhoods}

During the 19th century, an effort was made to transform Istanbul into a Western-style capital. This was a parallel of the general struggle to salvage the Ottoman Empire by reforming its traditional institutions by the integration of the structures of the Ottoman Empire with those of the world capitalist system (Dokmeci and Çiraci, 1988; Çelik, 1993; Kubat, 1999; Dokmeci and Çiraci, 1999). In order to westernize urban activities, it was necessary to transform the existing urban structure into one that followed a modern urban pattern. Neither the physical urban structure nor the urban services were sufficient to satisfy the growing requirements of the modern society of Beyoglu, which was largely habited by Europeans. To meet these demands, the westernization movement started in Beyoglu and continued in Macka, Nisantasi and Pangaltı (Celik, 1993). This trend later spread to Sisli with the development of more modern residential, 
commercial and recreation areas which later became a part of the new Istanbul CBD.

After the period of Tanzimat and the 1838 Trade Treaty, foreign trade and foreign influence reached a peak with the establishment of foreign banks, insurance companies, office buildings, hotels, churches, theaters, restaurants, large stores and retail passages, hospitals, schools, libraries, research institutes, archaeological institutes, clubs, embassy buildings, post offices and apartment buildings. Many of the new buildings were designed primarily by French and Italian architects, and as a result, Beyoglu became the most distinguished business, cultural and entertainment center of Istanbul. Public parks were planned, the streets were paved, the sewer system was established, and street lighting was provided by gas lamps. Its population rapidly increased; by the middle of the 19th century, its population was $47 \%$ foreign, 32\% nonMuslim, and only 21\% Muslim (Shaw, 1979). Since the topography of Beyoglu precluded any further expansion, the new influx of inhabitants soon resulted in a shortage of houses and thus in an increase in the price of land (Rosenthal, 1980). Rents were said to be as high as those of London and Paris. Eventually, a process of economic and social differentiation began as the extravagant prices paid by Europeans could not be matched by many Muslims, who then took up residence in other parts of the city (Rosenthal, 1980; Mansel, 1995). Finally, Beyoglu developed into a small westernized town with its own physical, social and economic lifestyle, and maintained this role until the 1970s. The main emphasis of westernization was to introduce new products, and encourage new tastes and a higher standard of living with a market dependent on European countries. The westernization of Beyoglu with respect to economic, administrative and technological development, and the modernization of social life, affected the urban form and resulted in a more 19th-century European image than those of the other districts of Istanbul. A century later, a similar trend was followed by globalization with respect to introducing new products and an international life-style (Figure 4).

After the 1970s, suburbanization started as a result of the construction of bridges over the Bosphorus and their associated peripheral highways. Although the residential buildings in the city center were largely abandoned by middle- and upper-class residents, businesses stayed active due to its central location and its position on one of the main transportation axes in Istanbul. The multi-center development of the city widely overshadowed its commercial life. After the pedestrianization of Beyoglu's main street in 1990, revitalization started and its beautiful historical 
stone buildings were restored and occupied mostly by artists, architects and young professionals. The restoration of the buildings was financed first by banks and local people, and later by the international investors due to the increasing high returns (Dokmeci and Ozus, 2005). Many restaurants, coffee shops, bars, book stores and hotels were opened. Its grid urban structure which is convenient for car traffic has helped the adaptation of modern activities. In addition, its hilltop location, which enjoys views of the Bosphorus and the Golden Horn, is undeniably an asset for its restoration value (Dokmeci and Ciraci, 1988). Now, it is one of the major tourist areas and has beautiful historical buildings and many entertainment and shopping activities. A metro connection to the new CBD in the north has also contributed to the continuous development of these neighbourhoods.

\section{KATIP çELEBi CIHANGIR}

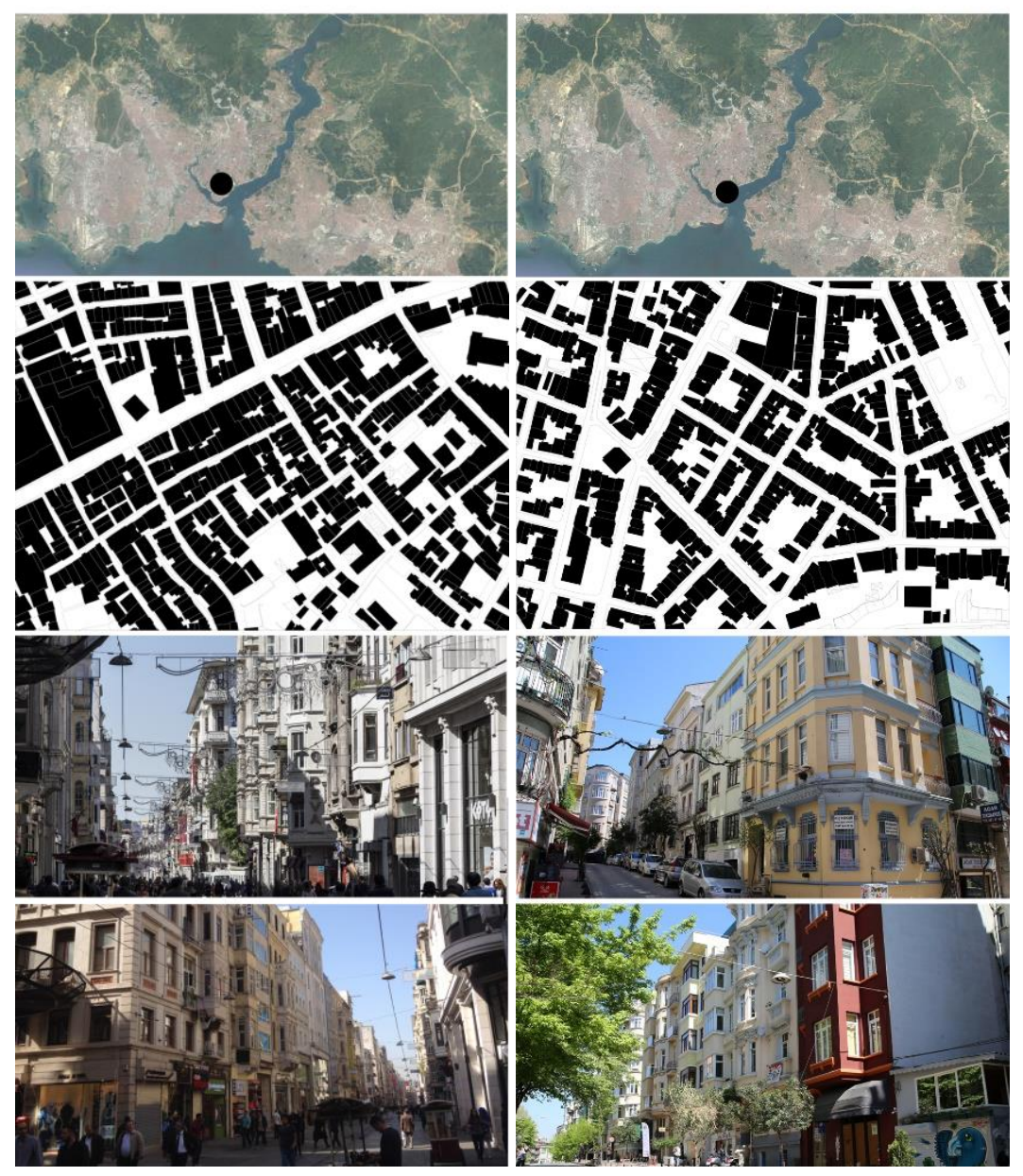

Figure 4. Two Neighbourhoods from Beyoglu: Katip Mustafa Celebi and Cihangir

\section{Modern and Post-Modern (Gated) Neighbourhoods}

The Levent Project is one of the few modern city projects in Istanbul (Figure -5). It was originally intended to be workers' housing to serve a nearby industrial site and was built on farm 
land given to Lamartine, who came to the Ottoman Empire as an agricultural advisor.

The system of the Levent Project (1947-1957), is unique. It was Istanbul's first garden city development, it was designed with curvilinear streets, it segregated pedestrian and vehicular traffic, and provided housing that blended urban and suburban amenities. Furthermore, it stimulated the development of the city toward the north along the main radial road (Buyukdere Caddesi) which later provided the backbone of the new business center of the city (Dokmeci and Berkoz, 1994; Oktem, 2011). The phases of the construction process consisted of the following housing units: 411 detached units in Levent-1; 1,319 detached units in Levent-2; 277 detached units in Levent-3; and multi-story buildings in Levent-4, including the tallest apartment building in Istanbul at that time. Under the deed restrictions, no structure could be built beyond its given floor limitations. Although this neighbourhood was planned according to zoning principles that ensured a separation of function in that commercial activities are located at the center of the neighbourhood and are removed from the residential zone, the houses located along Büyükdere Caddesi were later given over to commercial activities as a result of the influence of extensive commercial intrusion over time.

The modern city is accused of imposing a superficial life-style on other urban structures in place of long-standing cultural traditions. For instance, in a study by Bardo and Dokmeci (1992), while in Arnavutkoy, a historical neighbourhood, $75 \%$ of the inhabitants claimed to communicate with their neighbors, whereas in Atakoy, a modern neighbourhood, 95\% of people claimed not to do so. Therefore, on the one hand, modern city projects present a physically higher quality of urban life in Istanbul at the expense of the elimination of social interaction, which remains a characteristic of historical neighbourhoods.

Gated neighbourhoods emerged in Istanbul in the 1980s as a result of globalization and liberal socio-economic policies (Figure5). Gated neighbourhoods are a part of a trend of suburbanization that is based on the creation of self-contained, separate communities with carefully constructed identities and the hope of security and exclusivity. The typical patterns created by the rapid spread of proprietary urban communities have become a mark of urban development in the 21st century (Akgun and Baycan, 2011). As a result of greater levels of income disparity, gated neighbourhoods have increasingly became a major trend in the housing market in both developed and developing countries (Coy and Pöhler, 2002; Glasze and Alkhayyal , 2002; Gooblar 2002). Such neighbourhoods have dramatically restructured the urban 
pattern at the periphery of Istanbul. Initially, gated communities were built in areas close to the sub-centers in the north (GokturkKemerburgaz, Zekeriyakoy-Demircikoy), and south-west (Bahçesehir-Buyukcekmece) of the European side and in the north (Beykoz-Omerli) of the Asian side. However, they are now spreading all over the city.

LEVENT

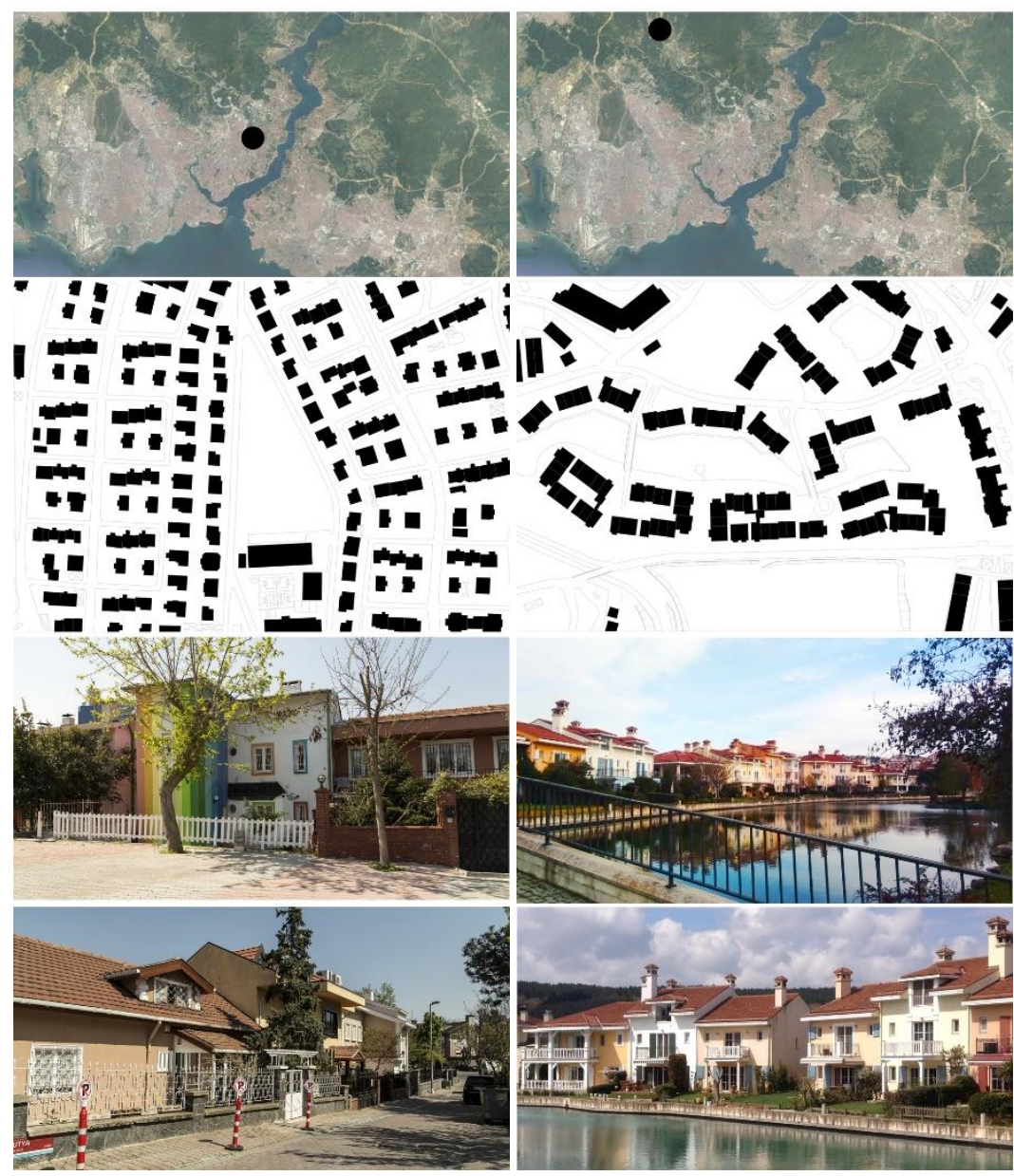

Figure 5. The Levent Project and A Gated Neighbourhood from the Periphery of Istanbul/Gokturk
The gated neighbourhoods in the north of Istanbul have been constructed within large green areas, creating pressure on the natural environment and posing a threat for the sustainability of natural resources and agricultural land (Akgun and Baycan, 2011).

\section{Manhattanization (Manhattan-type) Neighbourhoods}

Although the transformation of the city structure towards a new balance takes place mostly in small, time-consuming steps, after the 1970s, the construction of bridges over the Bosphorus and their associated peripheral highways provided the background for the development of a multi-centered city that arose due to the pressures from the increasing population and the demand for services (Dokmeci and Berkoz, 1994). 
At the beginning of the 21st century, the privatization of space stimulated several changes in the urban development process. Many construction companies grew in size and complexity and started to assume massive capacities. This change, alongside the changes in construction technology, has had major impacts on the urban form of Istanbul, as it has in examples from other countries (Whitehand, 1992).

As developing countries are linked with broader international capital markets and customers in general, and due to the relaxation of building regulations by the Istanbul municipal authority in particular, there has been a rush to build Manhattanstyle, luxurious high-rise residential buildings which are completely isolated from their surroundings. On the contrary of gated neighbourhood $s$, this new trend takes place both at central locations and the periphery. (Figure-6). As space is stripped of its social and cultural value, which can be developed only through people's use over time, it is treated as a mere commodity (Madanipour, 1996). Investors are only interested in the maximum possible returns and developers are increasingly erecting ever-taller residential buildings in Istanbul for the elite. Again, this has also occurred in some other developing metropolitan cities, such as in Mumbai (Bundhun, 2016). However, in every such case, the city's skyline is altered (Figure 7)

It is expected that increasing housing density might have some impact on the social psychology of residents, especially if they come from small neighbourhood s with close social ties. These problems have already been recorded in some developed countries, with the observation that people who live in single family-dwellings are considerably less neurotic than people who live in more crowded high-rise buildings. Additionally, people who live in high-rise buildings are reported to have fewer friends (Mehrabian, 1976; Gifford, 2007).

Thus, the review of the different neighbourhood s which were developed over time in Istanbul reveals that in more modern times, the street has lost its social and aesthetic value due to a combination of industrial and technological developments. The urban space has been shaped according to the motor car mobility, thereby changing the relationship between human beings and buildings, and between buildings and open spaces. The consequences of abolishing public spaces such as streets and squares have been studied by Madanipour (2003). The location of high-rise buildings ignores the necessity for spaces which allow sociability. After the static, enclosed public spaces of the past in both the East (Yenen, 1992) and the West (Ford, 1978), the 
modernist public spaces were to be free-floating and fast moving (Madanipour, 2003). However, the current trend for Manhattantype buildings in the sub-centers completely ignores the existence of pedestrians. The neighbourhood patterns of Istanbul have passed through various phases due to economic, administrative and technological changes. This was largely due to pressure from rapid population growth, and has resulted in very distinct forms of urban structure. For any new neighbourhood developments, the human-scale should be included before it is too late (Trancik, 1986; Talen, 2005).

\section{GÜZELTEPE}

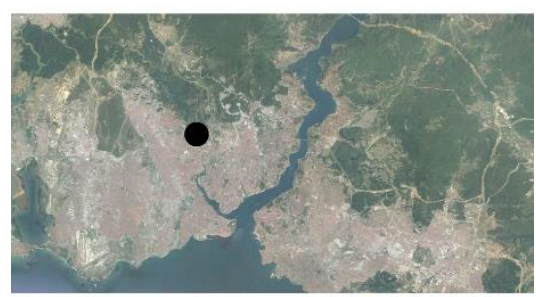

\section{FIKIRTEPE}

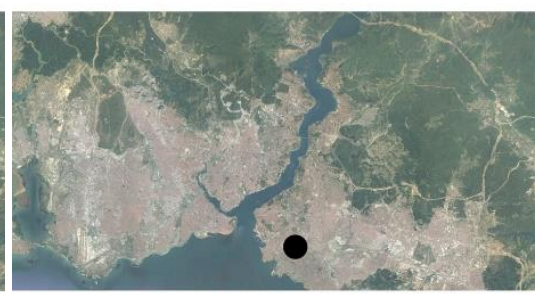

Figure 6. Manhattan Style high-rise Residential Buildings: Finanskent Güzeltepe and Fikirtepe

Figure 7. Distorted Silhouette of Istanbul
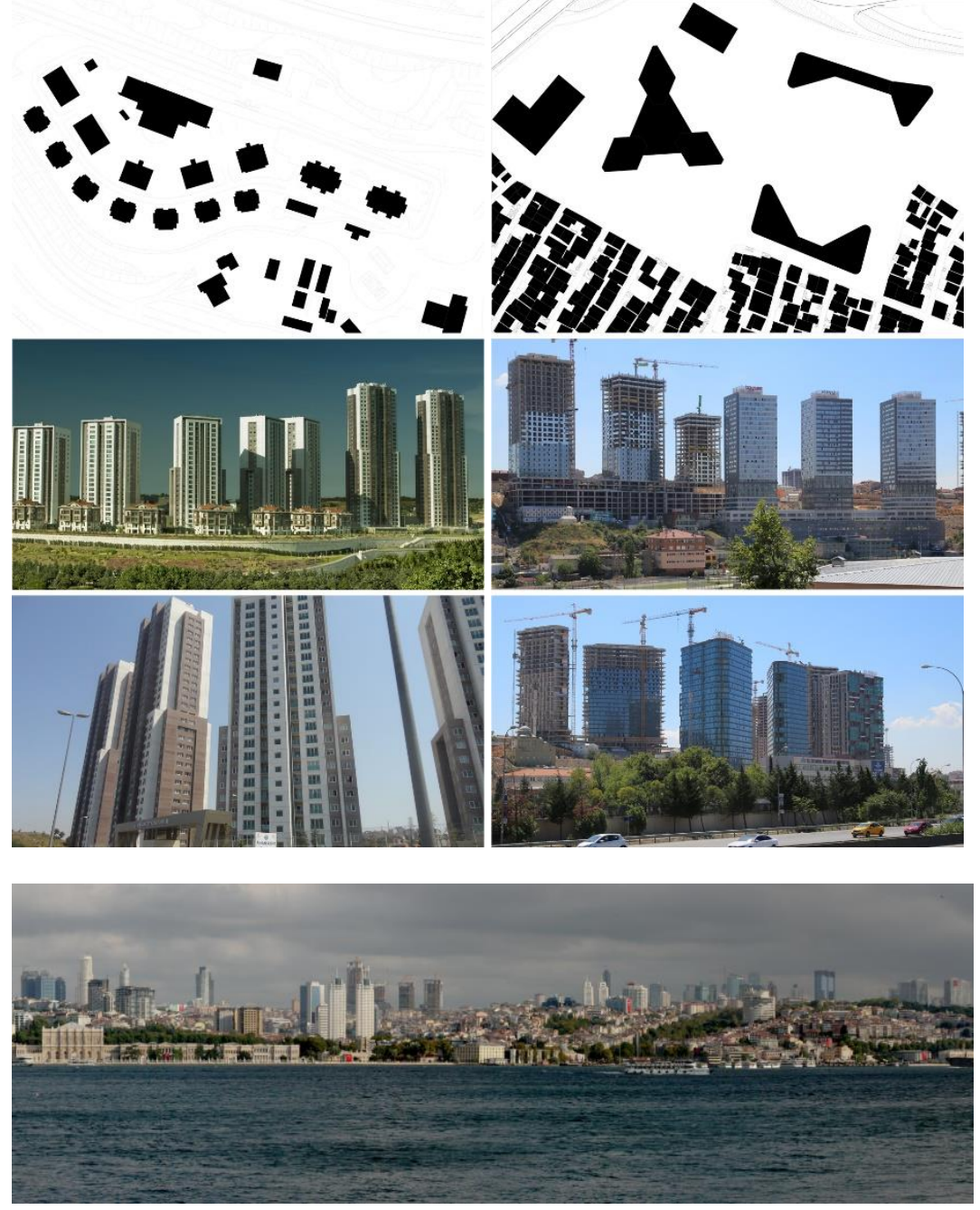


\section{CONCLUSION}

Change takes place in every historic city, but the type, rate, and impact of the change varies from place to place and according to socio-economic conditions. The differences in the characteristics of neighbourhood forms have their roots in specific social, cultural, physical, economic, political, technological, geographic and historical conditions as indicated in the previous studies (Asami et al., 2000; Whitehand, 2001; Yazgi and Dokmeci, 2009). Istanbul has a great variety of neighbourhood forms which have developed over different time periods, and which have been subject to different conditions. This paper presented the argument that while some traditional neighbourhoods still exist in Istanbul, the Manhattan-type high-rise residential building sector is booming as a result of globalization and the increase in land values and population. Meanwhile, the westernized districts which were developed in the 19th century, have been mostly preserved due to their splendid historical buildings and infrastructure, as well as their strategic location within the city with regard to trade, entertainment and tourism. Similarly, the modern neighbourhood s that were developed in the 1950s, have been preserved together with their green environments, despite their current locations in the middle of the new CBD and their proximity to high-rise office buildings. This has been achieved by their resistance to the pressure for increased building density and change to office functions. It is therefore possible to claim that Istanbul, being the most important socio-economic, educational and tourism centre of the country, has a very dynamic urban structure due to its rapidly increasing population and its strategic location.

Traditionally, the physical infrastructure of the city has been an implied framework within which social and material realities are interrelated. The present paper illustrates that while the core area (historical, westernized or modern) has mostly preserved its structures, if not its functions, the massive construction projects in zones, which promise higher returns, has distorted the worldfamous silhouette of Istanbul. These high-density projects were made in answer to the pressure of a rapidly increasing population, globalization and the desire to maximize the benefits for real estate investors. Thus, morphological continuity is accompanied by a radical transformation in the appearance of the city which stems from the advance of capitalism and its spatial relation as mentioned by Madanipour (2003). New neighbourhood projects are detached from local cultures, and their spatial expressions and income disparities are increasing. 
In order to provide continuity in the urban structure for future urban development projects, tradition should be a source-book of design elements and should be used to invent a new and a different future while pre-existing and underlying social structures are taken into consideration. For this purpose, it is necessary to provide a more balanced distribution of income and education level.

The results of the study are within the scope of urban and regional planners, policy makers and investors. Investigation of the impact of high-rise buildings on the traffic, noise, air pollution and health conditions of inhabitants, and the social production of their aesthetic effects on their surroundings is suggested for future research.

\section{REFERENCES}

Ahmad, N. (1992). Choice of location and mobility behavior of migrant in a third world city. Urban Studies, 29, 11471157.

Akgun, A.A. and Baycan, T. (2011). Gated communities in Istanbul: The new walls of the city. Town Planning Review, 83, 1, DOI: $10.3828 /$ tpr.2012.5

Aksoy, O. (1968). Osmanlı Devri Istanbul Sibyan Mektepleri Üzerine Bir İnceleme, Ph.D. Thesis. Istanbul Technical University.

Asami, Y., Kubat, A.S. and Istek, C. (2000). Characterization of the street networks in the Turkish urban form. Environment and Planning B: Planning and Design, 28, 5, 777-795.

Audirac, I. (2002). Information technology on urban forms. Journal of Planning Literature, 17, 2, 213-256.

Bardo, J.W. (1984). A reexamination of the neighbourhood as a socio-spatial schema. Social Inquiry, 54, 3, 346-357.

Bardo, J. W. and Dokmeci, V. (1992). Modernization, traditionalization and the changing structure of community satisfaction in two sub-communities in Istanbul, Turkey: Procrastination analysis. Genetic, Social and General Psychology Monographs, 118, 273-292.

Brower, S. (1992). Introduction: Influences on Urban form. Journal of Architectural and Planning Research, 9, 4 (Winter), 271-273.

Bundhun, R. (2016). Moving up, to escape the crowd. International New York Times, March 4, p.12.

Castells, M. (1994). European cities, the informational society, and the global economy. New Left Review, 204, 18-32.

Celik, Z. (1993). The Remaking of Istanbul: Portrait of an Ottoman City in the Nineteenth Century. Berkeley and Los Angeles, California: University of California Press.

Conzen, M.R.G. (2004). Thinking about Urban Form: Paper on Urban Morphology, 1932-1998. New York: Peter Lang.

Coy, P. and Pöhler, M. (2002). Gated communities in Latin American mega cities: Case studies in Brazil, and 
Argentina. Environment and Planning B: Planning and Design, 29, 355-370.

Dix, G. (1990). Conservation and change in the city. Third World Planning Review, 12, 385-406.

Dokmeci, V. and Berkoz, L. (1994). Transformation of Istanbul from a monocentric to a polycentric city. European Planning Studies, 2, 2, 193-205.

Dokmeci, V. and Ciraci, H. (1988). Pera: A threatened historic European city within Istanbul. Ekistics, 333, Nov.-Dec., 359-369.

Dokmeci, V., Berkoz, L., Levent, H., Yürekli, H. and Cagdas, G. (1996). Residential preferences in Istanbul. Habitat International, 20, 2, 241-251.

Dokmeci, V. and Ciraci, H. (1999). From westernization to globalization: An old district of Istanbul. Planning History, 21, 3, 99-109.

Dokmeci, V. and Berkoz, L. (2000). Residential-location preferencesaccording to demographic characteristics in Istanbul. Lanscape and Urban Planning, 48, 1-2, 45-53.

Dokmeci, V. and Ozus, E. (2005). Effects of revitalization in historical city center of Istanbul. International Real Estate Review, 8, 1, 144-159.

Ergun, N. and Dundar, B. (2004). Functional change as an indicator of transformation near the old city centre of Istanbul. European Planning Studies, 12, 5, 723-738.

Ford, L.R. (1978). Continuity and change in historic cities: Bath, Chester, and Norwich. The Geographical Review, 68, 3, 253-273.

Gifford, R. (2007). The consequences of living in high-rise buildings. Architectural Science Review, 50, 1, 2-17.

Glasze, G. and Alkhayyal, A. (2002). Gated housing estates in the Arab World: Case studies in Lebanon and Riyadh, Saudi Arabia. Environment and Planning B. Planning and Design, 29, 321-336.

Gooblar, A. (2002). Outside the walls: Urban gated communities and their regulation within the British Planning System. European Planning Studies, 10, 321-334.

Gur, E.A. (2015). Regeneration of the historical urban center and changing housing market dynamics: Fener-Balat. International Journal of Architectural Research, 9, 1, 232246.

Hunter, A. (1979). The urban neighbourhood : its analytical and social contexts. Urban Affairs, 14, 3, 267-288.

Jabareen, Y.R. (2006). Sustainable urbanforms: Their typologies, models, and concepts, Journal of Planning, Education and Research, 26, 1, 38-52.

Jo, S. (1998). Spatial configuration and built form. Journal of Urban Design, 3, 1, 285-301.

Kolcu, H. and Dokmeci, V. (2013). Analysis of Factors impacting land-use in transforming Istanbul historical city center. International Journal of Electronic, Mechanical and Mechatronics Engineering 3, 1, 477-492.

Kubat, A.S. (1999). The morphological history of Istanbul. Urban Morphology, 3, 28-41. 
Laskin, D.J. (2016). Into the soul of Venetian ghetto. International New York Times, p.21.

Lynch, K. and Rodwin, L. (1958). The theory of urban form. Journal of American Institute of Planners, 24, 4, 201-214.

Madanipour, A. (1996). Design of Urban Space. Chichester, Sussex: John Wiley.

Madanipour, A. (2003). Public and Private Space of the City, New York: Routledge.

Mansel, F. (1995). Constantinople: City of the World's Desires, 14531924, London: Murray.

McCann, E.J. (1995) Neotraditional developments-The anatomy of a new urban form. Urban Geography, 16, 3, 210-233.

Mesev, T.V., Longley, P.A., Batty, M., and Xie, Y. (1995). Morphology from imagery: detecting and measuring the density of urban land. Environment and Planning A, 27, 5, 759-780.

Mehrabian, A. (1976). Public Places and Private Spaces. New York: Basic Books Inc. Publishers.

Mitchell, K. (2000). The culture of urban space. Urban Geography, $21,5,443-449$.

Müller-Wiener, W. (1977). Bildlexikon Zur Topographie Istanbuls. Wasmuth Verlag, Tübingen.

Oktem, B. (2011). The role of global city discourses in the development and transformation of the BuyukdereMaslak Axis into the International Business District of Istanbul. International Planning Studies, 16, 1, 27-42.

Rahman, O. M. A. (1993). The central area of Alexandria, Egypt: Development implications and urban conservation. Third World Planning Review, 15, 1, 37-54.

Rosenthal, S.E. (1980). The Politics of Dependency: Urban Pattern in Istanbul. Westport, Connecticut: Greenwood Press.

Sassen, S. (1994). Cities in World Economy. Thousand Oaks, California: Pine Forge.

Senturk, T. and Dokmeci, V. (2010) Transformation of Istanbul's urban structure and its impact on real estate prices. Proceedings of 14th International Planning History Society Conference, July 12-15, Taşkışla, İTU, Istanbul.

Shaw, S.J. (1979). The population of Istanbul in the nineteenth century. International Journal of Middle East Studies, 10, 2, 265-277.

Song, Y. and Knaap, G.J. (2004). Measuring urban form. Journal of American Planning Association, 70, 2, 210-225.

Southworth, M. and Owens, P.M. (1993). The evolving Metropolis: Studies of community, neighbourhood, and street form at the urban edge. Journal of American Planning Association, $59,3,271-287$.

Talen, E. (2005). Evaluated good urban form in an inner-city neighbourhood : An empirical application. Journal of Architectural and Planning Research, 22, 3, 204-228.

Tarancik, R. (1986). Finding the Lost Space: Theories of Urban Design. New York: Van Nostrand Reinhold.

Whitehand, J.W.R. (1981). The Urban Landscape: The Historical Development and Management. Institute of British Geographers Special Publication, No.13. London: Academic Press. 
Whitehand, J. W. R. (1992). The Making of the Urban Landscape. Oxford: Blackwell.

Whitehand, J.W.R., Morton, N.J. and Carr, C.M.H. (1999). Urban morphogenesis at the microscale: how houses change. Environment and Planning A, 26, 503-515.

Whitehand, J. W. R. (2001). The physical form of cities, a historic geographical approach. Handbook of Urban Studies, London: Sage Publications.

Yazgi, B. and Dokmeci, V. (2006). Analysis of different urban forms in Istanbul. 46th Congress of the European Regional Science Association, Volos, Greece.

Yazgi, B. and Dokmeci, V. (2009). Spatial analysis of urban form in Istanbul metropolitan area. in Gulersoy, N., Gezici, F., Onem, A. B., Arslanli, K. Y. (Eds.) New Approaches in Urban and Regional Planning, Istanbul: Cenkler Printing Office, 253-264.

Yazgi, B., Dokmeci, V., Koramaz, K. and Kiroglu, G. (2014). Impact of characteristics of origin and destination on interprovincial migration in Turkey, 1995-2000. European Planning Studies, 22, 6, 1182-1198.

Yenen, Z. (1992). Social and religious influences on the form of early Turkish cities of the Ottoman Period. Journal of Architectural and Planning Research, 9, 4, 301-314.

Zukin, S. (1988). The post-modern debate over urban form. Theory, Culture and Society, 5, 431-46.

\section{Resume}

Assist.Prof.Dr. Gulden Demet Oruç is currently working at Istanbul Technical University, Faculty of Architecture, Urban and Regional Planning Department. Her research topics include urban design and planning.

Assoc.Prof.Dr. Özhan Ertekin is currently working at Istanbul Technical University, Faculty of Architecture, Urban and Regional Planning Department. His researches mainly focus on urban planning, regional planning, urban design, urban transformation and performance measurement. He had studied on measurement issues for a post-doc study in Regional Economics Applications Laboratory in University of Illinois at Urbana-Campaign in 2007.

Prof.Dr. Vedia Dökmeci is a professor emeritus of Istanbul Technical University, Faculty of Architecture, Urban and Regional Planning Department. Dr. Dökmeci has many publications, 7 books and was involved in numerous professional activities, including design competitions, research projects, and fellowships, many of which intersected urban and environmental planning. In 2001 she established Real Estate Development Master Program at Istanbul Technical University. 